medRxiv preprint doi: https://doi.org/10.1101/2020.06.29.20142091; this version posted July 3, 2020. The copyright holder for this preprint (which was not certified by peer review) is the author/funder, who has granted medRxiv a license to display the preprint in perpetuity.

All rights reserved. No reuse allowed without permission.

\title{
Airway expression of SARS-CoV-2 receptor, ACE2, and proteases, TMPRSS2 and furin, in severe asthma
}

Nazanin Zounemat Kermani ${ }^{1 *}$, Woo-Jung Song ${ }^{2,3^{*}}$, Alan Lunt ${ }^{1,2}$, Yusef Badi ${ }^{1,2}$, Ali Versi ${ }^{1,2}$, Yike Guo ${ }^{1}$, Kai Sun ${ }^{1}$, Pank Bhavsar ${ }^{2}$, Peter Howarth ${ }^{4}$, Sven-Erik Dahlen ${ }^{5}$, Peter J Sterk ${ }^{6}$, Ratko Djukanovic ${ }^{4}$, Ian M Adcock ${ }^{1,2}$, Kian Fan Chung ${ }^{1,2}$ on behalf the U-BIOPRED Consortium

${ }^{1}$ Department of Computing \& Data Science Institute, Imperial College London, United Kingdom;

${ }^{2}$ National Heart \& Lung Institute, Imperial College London; ${ }^{3}$ Department of Allergy and Clinical Immunology, Asan Medical Center, University of Ulsan College of Medicine, Seoul, Korea; ${ }^{4}$ Faculty of Medicine, Southampton University, Southampton, UK and NIHR Southampton Respiratory Biomedical Research Unit, University Hospital Southampton, Southampton, UK; ${ }^{5}$ Centre for Allergy Research, Karolinska Institute, Stockholm, Sweden; ${ }^{6}$ Amsterdam University Medical Centers, University of Amsterdam, Amsterdam, Netherlands.

*Contributed equally.

Running title: ACE2, TMPRSS2 and furin in severe asthma

\section{3 words; 3 Figures, 3 Tables}

\section{Supplementary data files: 1 Figure, 4 Tables, U-BIOPRED Consortium members}

\section{Corresponding author}

Professor K F Chung,

National Heart \& Lung Institute, Imperial College London,

Dovehouse St, London SW3 6LY, UK

f.chung@imperial.ac.uk

\section{"take home" message}

In severe asthma, gene expression of ACE, TMPRSS2 and furin are elevated compared to mildmoderate asthma and healthy volunteers, particularly in neutrophilic asthma. This might explain the increased risk of death in severe asthma afflicted with COVID19. 
medRxiv preprint doi: https://doi.org/10.1101/2020.06.29.20142091; this version posted July 3, 2020. The copyright holder for this preprint (which was not certified by peer review) is the author/funder, who has granted medRxiv a license to display the preprint in perpetuity.

All rights reserved. No reuse allowed without permission.

\section{Summary}

Background. Patients with severe asthma may have a greater risk of dying from COVID-19 disease caused by SARS-CoV-2 virus. Angiotensin converting enzyme 2 (ACE2) receptor and enzyme proteases, transmembrane protease, serine 2 (TMPRSS2) and furin are needed for the attachment and invasion of the virus into host cells. We determined whether their expression in the airways of severe asthma patients is increased.

Method. We examined the microarray mRNA expression of ACE2, TMPRSS2 and furin in the sputum, bronchial brush and bronchial biopsies of participants in the European U-BIOPRED cohort.

Results. ACE2 and furin sputum gene expression was significantly increased in severe non-smoking asthma compared to mild-moderate asthma and healthy volunteers. By contrast, TMPRSS2 expression in bronchial biopsy and bronchial brushings was increased in severe smoking and exsmoking asthmatics, and so was furin expression in bronchial brushings. Several clinical parameters including male gender, oral steroid use and nasal polyps were positively associated with ACE2, TMPRSS2 and furin expression levels. There was a higher expression of ACE2 and furin in the sputum neutrophilic molecular phenotype with inflammasome activation compared to the eosinophilic Type2-high or paucigranulocytic phenotypes. The enrichment score of the IL-13-Type2 gene signature was positively correlated with ACE2, TMPRSS2 and furin levels.

Conclusion. These key determinants of virus entry into the lungs may contribute to the poorer outcomes from COVID-19 disease in patients with severe asthma. 
medRxiv preprint doi: https://doi.org/10.1101/2020.06.29.20142091; this version posted July 3, 2020. The copyright holder for this preprint (which was not certified by peer review) is the author/funder, who has granted medRxiv a license to display the preprint in perpetuity.

All rights reserved. No reuse allowed without permission.

\section{Introduction}

Coronavirus disease 2019 (COVID-19) is posing un unprecedented impact on global health. COVID-19 infection caused by the new SARS-CoV-2 virus has been reported to be more common or severe in patients with older age or pre-existing conditions (1-5). However, it is unclear whether asthma is associated with poor clinical outcomes in COVID-19. Although a few studies did not find a significant association between asthma and critical outcomes in COVID-19 patients (1-5), they did not characterize asthma in detail, including clinical and inflammatory phenotypes. A recent large population-based study in UK reported a higher risk of death in patients with severe asthma who developed COVID-19 disease (6), with another study indicating that those with chronic lung disease also had a poorer outcome (3). Thus, it is reasonable to speculate that asthma heterogeneity, particularly severity, is an important factor in understanding the risk of fatal outcomes in COVID-19 among asthmatic patients.

The spike protein of SARS-CoV-2 binds to the angiotensin converting enzyme 2 (ACE2) receptor allowing the virus to attach to the cell membrane of the host (7). The next step for entry into the cell depends on the spike protein being degraded by host cell enzyme proteases, such as transmembrane protease, serine 2 (TMPRSS2) and furin also known as PACE (Paired basic $\underline{\text { Amino }}$ acid Cleaving Enzyme) $(8,9)$. Because this is the way by which SARS-CoV-2 infects and actively replicates in respiratory tract epithelial cells that expresses ACE2 receptors, we tested the hypothesis that the expression of these entry points for the virus may be different by asthma severity, and/or by clinical or molecular phenotypes.

We examined the transcriptomic data obtained from 3 airway compartment of airway cells, namely, bronchial brushings, bronchial biopsies and sputum-derived cells in patients with severe asthma from the U-BIOPRED (Unbiased BIOmarkers Predictive of REspiratory Disease outcomes) cohort (10) and analysed the expression of genes that encode for ACE2, TMPRSS2 and furin. We also examined the relationship of the gene expression with co-morbidities that are known to be associated with high risk for COVID-19 and asthma molecular phenotypes or transcriptomic associated clusters (TACS), previously identified in U-BIOPRED. 
medRxiv preprint doi: https://doi.org/10.1101/2020.06.29.20142091; this version posted July 3, 2020. The copyright holder for this preprint (which was not certified by peer review) is the author/funder, who has granted medRxiv a license to display the preprint in perpetuity.

All rights reserved. No reuse allowed without permission.

\section{Methods}

\section{Subjects}

The European-wide U-BIOPRED cohort consisted of 4 groups of participants: Group A: severe nonsmoking asthma (SAns), Group B: ever smokers with severe asthma (SAs), Group C: mild/moderate non-smoking asthmatics (MMA) and Group D: non-smoking healthy volunteers (HV) (10). Sputum cells, brushings of the lower airways, and bronchial biopsies (Supplementary Table S1) were obtained. Expression profiling was performed using U133 Plus 2.0 microarray (Affymetrix, Santa Clara, CA) on total RNA extracted and data assessed by multiarray average normalization. Demographics of the patients and healthy volunteers is shown in Supplementary Table S1. All UBIOPRED participants gave signed informed consent to participate in the study which was approved by the local Ethics Committee of each country.

\section{Data analysis and statistics}

Data were downloaded from the tranSMART platform (11). We analysed the gene expression of ACE2, TMPRSS2, and furin in the lower airway samples obtained from asthmatics and healthy subjects. A regression-based method (R package limma; version 3.45.0) was used to analyse these three genes with respect to the groups of interest, such as by the presence of asthma, across asthma severity subgroups, and also across 3 TACs (12). The presence of comorbidities (e.g. allergic rhinitis, nasal polyps, and eczema) was determined by physician diagnosis history. Age, sex, BMI (body mass index), and the use of oral corticosteroids (OCS) were adjusted for as covariates in the linear models. The Benjamini-Hochberg procedure controlled false discovery rate. Spearman's rank correlation was used for correlation analysis.

\section{Signatures summarised by gene set variation analysis}

Gene set variation analysis (GSVA) was used to calculate sample-wise enrichment scores (ESs) (13) for eight asthma-associated gene signatures. These gene sets each relate to a specific aspect of airway inflammation and asthma pathogenesis (Supplementary Table S2). The correlation between ESs and expression of ACE2, TMPRSS2, and furin was calculated using Spearman's correlation. For group comparison $P$ values were determined by differential expression analysis using moderated ttest, with adjustment for age, gender, body mass index and oral corticosteroid ( $R$ package limma; version 3.45.0). 
medRxiv preprint doi: https://doi.org/10.1101/2020.06.29.20142091; this version posted July 3, 2020. The copyright holder for this preprint (which was not certified by peer review) is the author/funder, who has granted medRxiv a license to display the preprint in perpetuity.

All rights reserved. No reuse allowed without permission.

\section{Results}

Intra-compartmental correlations of ACE2, TMPRSS2 and furin

ACE2, TMPRSS2 and furin mRNA expression was assessed in sputum (Fig 1A-C), bronchial brushing (Fig 1D-F), and bronchial biopsy (Fig 1G-I) compartments from HVs and asthmatics of different severity. There was no significant correlation between the expression of these three genes, in any compartment, except for a positive correlation between ACE2 and TMPRSS2 expression in sputum cells ( $n=89 ; r=0.252 ; p=0.010 ;$ Supplementary Table S3).

\section{Expression of ACE2}

Overall, the gene expression levels were not significantly different between HVs and asthmatics when asthmatics analysed as a single group (data not shown). However, differences were revealed when sub-grouped by asthma severity. There was a significant increase in the expression of ACE2 in SAns versus MMA and HV in sputum, when adjusted for age, gender and OCS use (Fig 1A). Within asthmatics, the levels of ACE2 in sputum were higher in males and those on OCS (Table 1), and the expression of ACE2 in sputum positively correlated with the blood neutrophil count $(r=0.21, p<0.05)$ and sputum neutrophil (\%) count ( $r=0.28, p<0.01$; Table 2). Expression levels of ACE2 mRNA were relatively lower in bronchial brushings and biopsies than in sputum (Supplementary Table S4). In bronchial brushings, ACE levels correlated with blood neutrophil count, but not with other baseline parameters $(r=0.21, p<0.05$; Table 2$)$. In bronchial biopsies, the expression levels of ACE2 were higher in patients with nasal polyps but was not associated with other baseline parameters (Table 2).

\section{Expression of TMPRSS2}

TMPRSS2 mRNA expression levels were higher in bronchial brushings than in sputum or bronchial biopsies (Supplementary Table S4). In bronchial brushings, there was a significantly increased expression of TMPRSS2 in SAs (versus MMA and HV) (Figure 1E), and the expression levels of TMPRSS2 positively correlated with blood neutrophils $(r=0.21, p<0.05)$ (Table 2$)$. In bronchial biopsies, TMPRSS2 levels were significantly higher in SAs (versus MMA and HV) (Figure $1 \mathrm{H}$ ) and were increased in subjects with nasal polyps but also in those without allergic rhinitis (Table 1). However, TMPRSS2 expression was similar across all groups in sputum (Fig 1B).

\section{Expression of furin}


medRxiv preprint doi: https://doi.org/10.1101/2020.06.29.20142091; this version posted July 3, 2020. The copyright holder for this preprint (which was not certified by peer review) is the author/funder, who has granted medRxiv a license to display the preprint in perpetuity.

All rights reserved. No reuse allowed without permission.

Expression levels of furin were higher in sputum than in bronchial brushings and biopsies (Supplementary Table S4). In sputum, expression of furin was significantly greater in SAns compared to MMA and HVs (Fig 1C). Within the whole asthmatic group, sputum furin levels negatively correlated with FEV1 (\% of predicted) $(r=-0.21, p<0.05)$ and FeNO levels $(r=-0.26, p<0.05)$, but positively with blood neutrophil count $(r=0.24, p<0.05)$ and stronger with sputum neutrophil $(\%)$ $(r=0.6, p<0.001)$ (Table 2). Meanwhile, in bronchial brushings, furin level was significantly higher in SAs than HVs (Figure 1F); however, it did not correlate with clinical parameters (Tables 1 and 2). Furin levels in bronchial biopsy were not significantly different across groups or by clinical parameters (Figure $1 \mathrm{l}$ and Tables 1 and 2).

\section{Expression of ACE2, TMPRSS2 and furin in molecular phenotypes of asthma}

We determined the expression of these three genes in sputum amongst the three previously identified TACs $(12,14)$. As previously described, analysis of sputum transcriptomics in U-BIOPRED produced three molecular endotypes (12). The expression of ACE2 was highest in TAC2, an endotype characterized by sputum neutrophilic inflammation and inflammasome activation signature, compared to TAC1 (eosinophilic inflammation, T2-high) and TAC3 (paucigranulocytic inflammation), with levels higher than in HVs (Fig 2A). Furin expression showed a similar trend as that of ACE2 with the highest expression in TAC2, significantly higher than in TAC1 (Fig 2C). There was no significant difference in TMPRSS2 expression among the three TACs (Fig 2B).

\section{Gene signatures and expression of ACE2, TMPRSS2 and furin}

To further determine the relationship between gene signatures of interest and the expression levels of ACE2, TMPRSS2 and furin, we measured by GSVA the ESs of IL-13-Th2, eosinophil activation, IL17, neutrophil activation, IL-6-trans-signalling (IL-6-TS), and inflammasome signatures (Supplementary Table S2). The ES of IL-13-Th2 signature showed positive correlations with ACE2, TMPRSS2 and furin levels in the majority of compartments analysed (Table 3). The ES of eosinophil activation weakly correlated weakly with ACE2 in sputum $(r=0.18, p<0.05)$, and with furin in bronchial biopsies $(r=0.26, p<0.05)$. However, furin levels in all 3 compartments correlated with the neutrophil activation and IL-6-TS signatures with the highest correlation in sputum $(r=0.51, p<0.001$; and $r=0.54, p<0.001$, respectively). Inflammasome activation also significantly correlated with furin levels in sputum $(r=0.49, p<0.001)$ and in bronchial brushings $(r=0.30, p<0.001)$. 
medRxiv preprint doi: https://doi.org/10.1101/2020.06.29.20142091; this version posted July 3, 2020. The copyright holder for this preprint (which was not certified by peer review) is the author/funder, who has granted medRxiv a license to display the preprint in perpetuity.

All rights reserved. No reuse allowed without permission.

\section{Discussion}

COVID-19 is a disease that spreads easily, hence the pandemic, causes severe illness in around $20 \%$ of affected individuals, with up to $33 \%$ deaths in those admitted to hospital. The factors that determine the clinical picture are slowly becoming apparent, but elucidation of the molecular mechanisms that must be the defining factors for all clinical disease has not been achieved, especially in the context of individual chronic diseases, like asthma, and the various phenotypes of this condition that varies from mild to very severe. Analysing three cell compartments (biopsies, brushings, and sputum cells) this study provides compelling evidence for over expression of the factors that may determine the entry of the SARS-CoV2 into cells, ACE2, TMPRSS2 and furin in severe asthma. In contrast, their expression in mild to moderate asthmatics compared to mild-moderate asthma was similar to healthy controls. Together, these observations suggest that patients with severe asthma, and not those with mild disease, have the pathobiological substrate that determines the strength of infection by SARS-CoV-2. Our findings also suggest that the associations between SARS-CoV2 infection and asthma are likely to be complex, and support the epidemiological observation (6) that severe asthma may increase the risk of severe morbidity or mortality if infected with SARS-CoV-2 virus with increased probability in males, OCS users or those with comorbid nasal polyps.

In sputum, ACE2 and furin were most highly expressed in severe non-smoking asthma (SAns), while in bronchial biopsies and bronchial brushings, TMPRSS2 was more highly expressed in severe smoking/ex-smoking asthma (SAs). Further analysis suggested that several factors including male gender, OCS use or comorbid nasal polyps have a higher expression of these genes in sputum, bronchial biopsies or bronchial brushings. We also found that a specific molecular cluster (TAC2) in asthma, characterized by predominant sputum neutrophilic inflammation and inflammasome activation (12), had a higher expression of ACE2 and furin, than the other TACs. It was followed by TAC1, a predominantly sputum eosinophilic phenotype with the highest enrichment of gene signatures for IL-13/Type-2 (T2) inflammation, and lowest in TAC3, with a paucigranulocytic sputum associated with mild eosinophilia and increased metabolic and mitochondrial function genes. However, the expression of TMPRSS2 was not different amongst the 3 TACs or compared to healthy individuals. These findings are supported by the significant correlations between ACE2 and furin expression with gene signatures of relevance to asthma, such as neutrophil activation, IL-6-TS, inflammasome, or IL13-Th2 pathways. Thus, there is the possibility that these pathways may 
medRxiv preprint doi: https://doi.org/10.1101/2020.06.29.20142091; this version posted July 3, 2020. The copyright holder for this preprint (which was not certified by peer review) is the author/funder, who has granted medRxiv a license to display the preprint in perpetuity.

All rights reserved. No reuse allowed without permission.

increase the expression of ACE2 or furin. Collectively, these suggest that molecular heterogeneity may be associated with the varying risk of severe COVID-19 outcomes in asthmatics.

Olfactory and taste disturbance is a common symptom of COVID-19, and the nasal epithelium is suggested to be a major route of viral infection $(15,16)$. In this study, we did not report nasal brushing data in detail, as three gene expression levels in nasal brushings did not differ by asthma severity or molecular phenotype (data not presented) and also were not significantly different in those with nasal polyps (Supplementary Fig S1). However, the absolute gene expression levels were higher in nasal brushings than in other airway compartments (Supplementary Table S4), supporting a recent expression analysis report (16). Based on the expression patterns in the upper and lower airways, we suggest that severe asthmatics might have a higher risk of poorer outcomes from COVID-19, although the risk of infection via the nasal route is unlikely to be different.

A strength of our analysis is that it evaluates expression in a range of airway cell populations (epithelial brushings, bronchial biopsies and sputum cells) in well-characterised subjects allowing, particularly in severe asthma, assessment in different sub-divided, phenotypic populations. Like a recent publication that found no difference in gene expression of ACE2, TMPRSS2 and furin between healthy, mild-to-moderate asthma and severe asthma in bronchial brush samples, we did not find differences when the severe asthmatics were those classified as non-smokers but did find differences in those with severe asthma who were either current smokers or ex-smokers with a 5pack-year history or more. By contrast it was only the severe non-smoking asthmatics that had increased gene expression of ACE2 and TMPRSS2 in sputum, a difference that was not evident when mild/moderate and severe asthma were all included as a mixed asthma population in a previous study (17).

Consistent with the importance of focusing on phenotypic populations, in asthmatic children with respiratory allergy and allergen exposure have reduced levels of ACE2 expression in nasal/bronchial epithelial brushings compared to those without allergies (18). Similarly, in bronchial brushings in adults with mild-moderate asthma, ACE2 expression has been reported to be significantly reduced in those defined as T2-high asthma (high expression of three-gene signature; CLCA1, POSTN, SERPINB2) compared to those with T2-low asthma (19). Our failure to confirm these findings in severe asthma may be due to confounding by therapy, the nature of the underlying type 2 inflammatory process (Th2 allergen driven vs ILC2 non-allergen driven) as well as the analytic approach. Using GSVA, we showed that the expression of the T2 signature to correlate positively with the expression of the 3 genes in most of the 3 compartments, while the neutrophil activation 
medRxiv preprint doi: https://doi.org/10.1101/2020.06.29.20142091; this version posted July 3, 2020. The copyright holder for this preprint (which was not certified by peer review) is the author/funder, who has granted medRxiv a license to display the preprint in perpetuity.

All rights reserved. No reuse allowed without permission.

signature was only correlated with furin expression. These differences may reflect the complexity of asthma driving mechanisms whereby the presence of differing percentages of Th2, Th17 and Th1 pathways in each asthmatic individual $(20,21)$ may effect upon the overall expression of the SARSCoV-2 entry and activation genes.

Another strength of our study is the large sample size and the fact that the U-BIOPRED cohort came from one single large study that recruited healthy controls, mild-moderate asthmatics and severe asthmatics using the same pre-defined protocol. In addition, we compared the expression of these three pivotal genes for SARS-CoV-2 virus entry in three different compartments of relevance: bronchial epithelial cells from brushings, bronchial biopsy with epithelial and submucosal cells and sputum cells with granulocyte inflammation. It is this uniform approach that gives confidence in the observation that the levels of ACE2, TRPMSS2 and furin are higher in severe asthma compared to mild moderate asthma, particularly in males, with nasal polyps or on oral corticosteroid therapy, and those with an eosinophilic and neutrophilic inflammation. However, a limitation of our study is that these data cannot apportion cause and effect as this is a comparative study with correlation analyses. In addition, we do not know whether the increased gene expression is associated with greater protein expression. Further studies are therefore warranted.

\section{Acknowledgements}

U-BIOPRED was supported by an Innovative Medicines Initiative Joint Undertaking (No.115010), resources from the European Union's Seventh Framework Programme (FP7/2007-2013) and EFPIA companies' in-kind contribution (www.imi.europa.eu). We thank the U-BIOPRED Project team for their contribution. 
medRxiv preprint doi: https://doi.org/10.1101/2020.06.29.20142091; this version posted July 3, 2020. The copyright holder for this preprint (which was not certified by peer review) is the author/funder, who has granted medRxiv a license to display the preprint in perpetuity.

All rights reserved. No reuse allowed without permission.

\section{Legend to Figures:}

Fig 1. Comparison of ACE2, TMPRSS2 and furin gene expression levels (box-and-whisker plots showing median and interquartile range) between healthy volunteers and asthmatics in different airway compartments. ACE2 $(A, D, G)$, TMPRSS2 $(B, E, H)$ and furin $(C, F, I)$ mRNA expression was assessed in (A) ACE2 in sputum (A-C), bronchial brushings (D-F), and bronchial biopsies (G-I) compartments from healthy volunteers and asthmatics of different severity. Abbreviations: SA.ns, severe asthmatics with no smoking history; SA.s, severe asthmatics with ever smoking history; MMA, mild-to-moderate asthmatics; HV, healthy volunteers; $n s$, not significant $(p>0.05)$. $P$ values were determined by differential expression analysis: moderated t-test, with adjustment for age, gender, and oral corticosteroid use.

Fig 2. Comparison of (A) ACE2, (B) TMPRSS2 and (C) furin gene expression levels across transcriptomic-associated clusters in sputum samples. Data shown as box-and-whisker plots showing median and interquartile range. Abbreviations: HV, healthy volunteers; TAC, transcriptomic-associated cluster; ns, not significant $(p>0.05)$. $P$ values were determined by differential expression analysis: moderated t-test, with adjustment for age, gender, body mass index and oral corticosteroid use.

Fig 3. Upper panel: Interaction of the spike proteins of SARS-CoV-2 virus with the ACE2 receptor on host cell membrane, followed by the proteases, furin and TMPRSS2, on the exterior of the host cell breaks the spike protein at one or more cleavage sites. Fusion peptides are exposed fusing with the viral membrane with the host membrane. Lower panel: Expression levels of ACE2, TMPRSS2 and furin in sputum, bronchial brushings and bronchial biopsies of patients with severe non-smoking asthma and severe smoking/ex-smoking asthma compared to healthy volunteers. 
Table 1. SARS-CoV-2 entry-related gene expression (Z-score) in the lower airways and their associations with baseline parameters within asthmatics

\begin{tabular}{|c|c|c|c|c|c|c|c|c|c|}
\hline \multirow[b]{2}{*}{ Parameters } & \multicolumn{3}{|c|}{ Sputum $(n=104)$} & \multicolumn{3}{|c|}{ Bronchial brushing $(n=103)$} & \multicolumn{3}{|c|}{ Bronchial biopsy $(n=81)$} \\
\hline & ACE2 & TMPRSS2 & Furin & ACE2 & TMPRSS2 & Furin & ACE2 & TMPRSS2 & Furin \\
\hline \multicolumn{10}{|l|}{ Gender } \\
\hline Male & $0.32(-0.56 \text { to } 1.7)^{* *}$ & $0.01(-1.57$ to 1.4$)$ & $0.05(-0.88$ to 0.6$)$ & $-0.06(-0.88$ to 1.1$)$ & $0.61(-0.73$ to 1.7$)$ & $0.08(-0.49 \text { to } 0.98)^{* *}$ & $-0.23(-1.16$ to 1.1$)$ & $1.25(-1.03$ to 2.4$)$ & $-0.03(-0.55$ to 0.7$)$ \\
\hline \multicolumn{10}{|l|}{ Smoking } \\
\hline Never & $0.06(-0.82$ to 1.3$)$ & $-0.30(-1.78$ to 1$)$ & $0.07(-0.61$ to 0.7$)$ & $-0.39(-1.22$ to 0.8$)$ & $-0.01(-1.36$ to 1.4$)$ & $-0.25(-0.73$ to 0.5$)$ & $-0.37(-0.95$ to 0.8$)$ & $0.1(-1.34$ to 1.4$)$ & $-0.03(-0.60$ to 0.7$)$ \\
\hline \multicolumn{10}{|l|}{ Nasal polyps } \\
\hline No & $-0.50(-1.2$ to 1$)$ & $-0.40(-1.83$ to 1$)$ & $-0.02(-0.78$ to 0.6$)$ & $-0.01(-1.04$ to 1$)$ & $-0.004(-1.0$ to 1.2$)$ & $-0.32(-0.74$ to 0.4$)$ & $-0.38(-1.16 \text { to } 0.7)^{*}$ & $0.09(-1.39 \text { to } 1.3)^{*}$ & $-0.04(-0.57$ to 0.6$)$ \\
\hline Yes & $0.21(-0.17$ to 1.1$)$ & $0.09(-1.49$ to 2.2$)$ & $0.23(-0.51$ to 0.9$)$ & $-0.39(-0.93$ to 0.4$)$ & $1.2(-0.46$ to 2.1$)$ & $-0.18(-0.64$ to 0.6$)$ & $0.63(-0.69 \text { to } 2)^{*}$ & $1.61(-0.05 \text { to } 2.7)^{*}$ & $-0.16(-0.64$ to 0.7$)$ \\
\hline \multicolumn{10}{|c|}{ Allergic rhinitis } \\
\hline No & $-0.14(-1.11$ to 1$)$ & $-0.29(-1.83$ to 1.3$)$ & $0.07(-0.82$ to 0.6$)$ & $-0.23(-1.24$ to 0.7$)$ & $0.08(-0.98$ to 1.6$)$ & $-0.26(-0.75$ to 0.4$)$ & $-0.45(-1.22$ to 0.8$)$ & $0.9(-0.64 \text { to } 2.5)^{*}$ & $-0.03(-0.57$ to 0.8$)$ \\
\hline Yes & $-0.08(-0.64$ to 1$)$ & $-0.04(-1.71$ to 1.8$)$ & $0.07(-0.42$ to 0.9$)$ & $-0.27(-0.87$ to 1.1$)$ & $0.38(-0.90$ to 1.5$)$ & $-0.26(-0.67$ to 0.5$)$ & $-0.15(-0.77$ to 0.9$)$ & $0(-1.9 \text { to } 1.4)^{*}$ & $-0.03(-0.55$ to 0.6$)$ \\
\hline No & $-0.07(-0.88$ to 1$)$ & $-0.04(-1.90$ to 1.8$)$ & $-0.03(-0.82$ to 0.6$)$ & $-0.38(-1.23$ to 0.8$)$ & $-0.09(-0.97$ to 1.2$)$ & $-0.22(-0.7$ to 0.6$)$ & $-0.38(-0.99$ to 0.7$)$ & $0.3(-1.08$ to 2.3$)$ & $-0.04(-0.7$ to 0.6$)$ \\
\hline Yes & $-0.30(-1.27$ to 1.3$)$ & $-0.98(-1.81$ to 1$)$ & $0.22(-0.29$ to 1$)$ & $0.32(-0.8$ to 1.1$)$ & $0.64(-0.90$ to 1.6$)$ & $-0.28(-0.75$ to 0.3$)$ & 0.02 (-1.01 to 1.1$)$ & $0.3(-1.33$ to 1.9$)$ & $0.003(-0.52$ to 0.6$)$ \\
\hline \multicolumn{10}{|l|}{ OCS use } \\
\hline No & $-0.48(-1.17 \text { to } 0.6)^{*}$ & $-0.33(-1.82$ to 1.4$)$ & $0.04(-0.57$ to 0.7$)$ & $-0.04(-1.02$ to 1.1$)$ & $-0.002(-0.98$ to 1.6$)$ & $-0.20(-0.74$ to 0.6$)$ & $0.2(-0.96$ to 1.1$)$ & 0.1 (-1.40 to 1.6$)$ & $-0.04(-0.68$ to 0.6$)$ \\
\hline Yes & $0.42(-0.39 \text { to } 1.3)^{*}$ & $-0.04(-1.64$ to 2.2$)$ & $0.08(-0.62$ to 0.8$)$ & $-0.45(-0.95$ to 0.3$)$ & $1.06(-0.06$ to 1.9$)$ & $-0.27(-0.68$ to 0.9$)$ & $-0.6(-1.11$ to 0$)$ & $0.5(-0.73$ to 2.3$)$ & $-0.06(-0.39$ to 0.7$)$ \\
\hline \multicolumn{10}{|l|}{ Atopy } \\
\hline No & $-0.04(-1.19$ to 2$)$ & $-0.43(-2.33$ to 1.7$)$ & $0.2(-0.17$ to 0.8$)$ & $-0.74(-1.1 \text { to }-0.13)^{*}$ & $0.07(-0.74$ to 0.9$)$ & $-0.61(-0.73$ to 0.5$)$ & $-0.05(-0.94$ to 0.7$)$ & $0.09(-0.62$ to 2.3$)$ & $0.01(-0.52$ to 0.7$)$ \\
\hline Yes & $-0.10(-0.90$ to 0.7$)$ & $-0.09(-1.54$ to 1.2$)$ & $0(-0.68$ to 0.7$)$ & $0.13(-0.71 \text { to } 1.19)^{*}$ & $0.37(-1.07$ to 1.7$)$ & $-0.16(-0.66$ to 0.6$)$ & $-0.37(-1.04$ to 1.1$)$ & $0.23(-1.49$ to 1.6$)$ & $-0.09(-0.70$ to 0.6$)$ \\
\hline
\end{tabular}

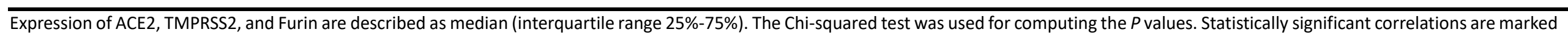

bold and also indicated as follows: ${ }^{*} p<0.05 ;{ }^{* *} p<0.01$; otherwise non-significant $(p>0.05)$. 
Table 2. Correlations between baseline parameters and ACE2, TMPRSS2 and Furin gene expression in asthmatics

\begin{tabular}{|c|c|c|c|c|c|c|c|c|c|}
\hline \multirow[b]{2}{*}{ Parameters } & \multicolumn{3}{|c|}{ Sputum $(n=104)$} & \multicolumn{3}{|c|}{ Bronchial brushing $(n=103)$} & \multicolumn{3}{|c|}{ Bronchial biopsy $(n=81)$} \\
\hline & ACE2 & $\begin{array}{l}\text { TMPRSS2 } \\
\end{array}$ & Furin & ACE2 & TMPRSS2 & Furin & ACE2 & TMPRSS2 & Furin \\
\hline Age (years) & $r=0.14$ & $r=-0.03$ & $r=0.11$ & $r=-0.01$ & $r=0.07$ & $r=0.04$ & $r=0.01$ & $r=0.23^{*}$ & $r=-0.16$ \\
\hline $\mathrm{BMI}\left(\mathrm{kg} / \mathrm{m}^{2}\right)$ & $r=0.04$ & $r=0.12$ & $r=0.05$ & $r=0.04$ & $r=0.1$ & $r=-0.05$ & $r=-0.12$ & $r=0.07$ & $r=-0.06$ \\
\hline FEV1\% predicted & $r=-0.17$ & $r=-0.04$ & $r=-0.21^{*}$ & $r=-0.06$ & $r=-0.14$ & $r=-0.19$ & $r=-0.08$ & $r=-0.23^{*}$ & $r=0.04$ \\
\hline FeNO (ppb) & $r=0.06$ & $r=0.01$ & $r=-0.26^{*}$ & $r=0.11$ & $r=0.05$ & $r=-0.04$ & $r=-0.01$ & $r=-0.1$ & $r=-0.04$ \\
\hline Total IgE (IU/mL) & $r=0.14$ & $r=0$ & $r=0.02$ & $r=0.18$ & $r=0.19$ & $r=0.02$ & $r=0.15$ & $r=0$ & $r=-0.12$ \\
\hline Serum periostin $(\mathrm{ng} / \mathrm{mL})$ & $r=0.08$ & $r=0$ & $r=0.08$ & $r=-0.09$ & $r=-0.24^{*}$ & $r=0.01$ & $r=0.06$ & $r=-0.02$ & $r=-0.16$ \\
\hline Blood eosinophils (x 109/L) & $r=0.18$ & $r=0.03$ & $r=0.02$ & $r=0.07$ & $r=-0.02$ & $r=0.13$ & $r=-0.07$ & $r=-0.01$ & $r=-0.03$ \\
\hline Blood neutrophils (x 109/L) & $r=0.21^{*}$ & $r=0.06$ & $r=0.24^{*}$ & $r=0.21^{*}$ & $r=0.21^{*}$ & $r=0.17$ & $r=0.15$ & $r=0.34^{* *}$ & $r=0.15$ \\
\hline Sputum eosinophil \% & $r=0.07$ & $r=-0.03$ & $r=-0.1$ & $r=-0.11(\mathrm{n}=43)$ & $r=0.01(\mathrm{n}=43)$ & $r=-0.12(n=43)$ & $r=0.03(n=35)$ & $r=0(\mathrm{n}=35)$ & $r=0.1(\mathrm{n}=35)$ \\
\hline Sputum neutrophil \% & $r=0.28^{* *}$ & $r=0.13$ & $r=0.6 * * *$ & $r=0.07(n=43)$ & $r=0(n=43)$ & $r=0.24(\mathrm{n}=43)$ & $r=0.26(\mathrm{n}=35)$ & $r=-0.03(\mathrm{n}=35)$ & $r=-0.06(\mathrm{n}=35)$ \\
\hline
\end{tabular}

Abbreviations: BMI, body mass index; FEV1, forced expiratory volume in 1 second; FeNO, exhaled nitric oxide fraction.

Association of ACE2, TMPRSS2, and furin expression with numerical variables were measured and tested using Spearman's rank-order correlation. Statistically significant correlations are marked bold and also indicated as follows: ${ }^{*} p<0.05 ;{ }^{* *} p<0.01 ;{ }^{* * *} p<0.001$. Otherwise non-significant $(p>0.05)$. 
Table 3. Summary of correlations between SARS-CoV-2 entry-related gene expression and asthma-associated gene signatures.

\begin{tabular}{|c|c|c|c|c|c|c|}
\hline & \multicolumn{5}{|c|}{ Asthma-associated gene signature } & \multirow[b]{2}{*}{ Inflammasome } \\
\hline & IL13 Th2 & Eosinophils & Th17 & Neutrophil & IL-6-TS & \\
\hline \multicolumn{7}{|l|}{ ACE2 } \\
\hline Sputum $(n=120)$ & $r=0.38 * * *$ & $r=0.18 *$ & $r=-0.23 *$ & $r=0.02$ & $r=0.14$ & $r=0.07$ \\
\hline Bronchial brushing $(n=149)$ & $r=0.12$ & $r=-0.07$ & $r=-0.11$ & $r=0.0005$ & $r=0.11$ & $r=0.20^{*}$ \\
\hline Bronchial biopsy $(n=108)$ & $r=0.23^{*}$ & $r=0.02$ & $r=-0.12$ & $r=-0.11$ & $r=0.01$ & $r=0.14$ \\
\hline \multicolumn{7}{|l|}{ TMPRSS2 } \\
\hline Sputum $(n=120)$ & $r=0.57 * * *$ & $r=0.15$ & $r=-0.06$ & $r=0.03$ & $r=0.02$ & $r=0.10$ \\
\hline Bronchial brushing $(n=149)$ & $r=0.36 * * *$ & $r=-0.04$ & $r=-0.10$ & $r=-0.06$ & $r=-0.07$ & $r=-0.06$ \\
\hline Bronchial biopsy ( $n=108)$ & $r=0.37 * * *$ & $r=-0.14$ & $r=-0.30 * *$ & $r=-0.14$ & $r=-0.01$ & $r=-0.01$ \\
\hline \multicolumn{7}{|l|}{ Furin } \\
\hline Sputum $(n=120)$ & $r=0.10$ & $r=0.13$ & $r=-0.16$ & $r=0.51 * * *$ & $r=0.54 * * *$ & $r=0.49 * * *$ \\
\hline Bronchial brushing $(n=149)$ & $r=0.30 * * *$ & $r=0.14$ & $r=0.10$ & $r=0.24 * *$ & $r=0.30 * * *$ & $r=0.30 * * *$ \\
\hline Bronchial biopsy $(n=108)$ & $r=0.33 * * *$ & $r=0.26 * *$ & $r=0.06$ & $r=0.20 *$ & $r=0.23^{*}$ & $r=0.15$ \\
\hline
\end{tabular}

Association of ACE2, TMPRSS2, and Furin expression with asthma-associated gene signatures were measured and tested using Spearman's rank-order correlation. Statistically significant correlations are marked bold and also indicated as follows: ${ }^{*} p<0.05 ;{ }^{* *} p<0.01 ;{ }^{* * *} p<0.001$. Otherwise non-significant ( $\left.p>0.05\right)$. IL-6-TS, IL-6-trans-signalling 
medRxiv preprint doi: https://doi.org/10.1101/2020.06.29.20142091; this version posted July 3, 2020. The copyright holder for this preprint (which was not certified by peer review) is the author/funder, who has granted medRxiv a license to display the preprint in perpetuity.

All rights reserved. No reuse allowed without permission.

Fig 1.

(A) tissue: SPUTUM

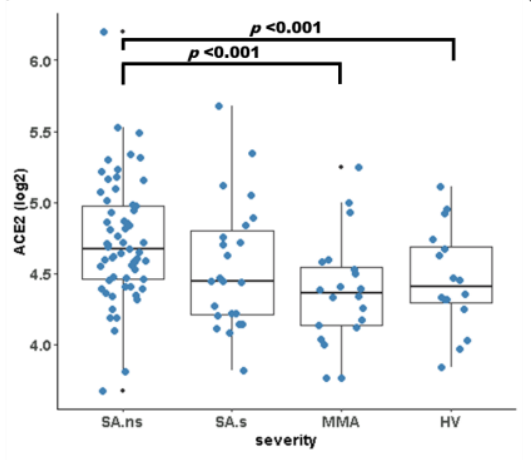

(D)

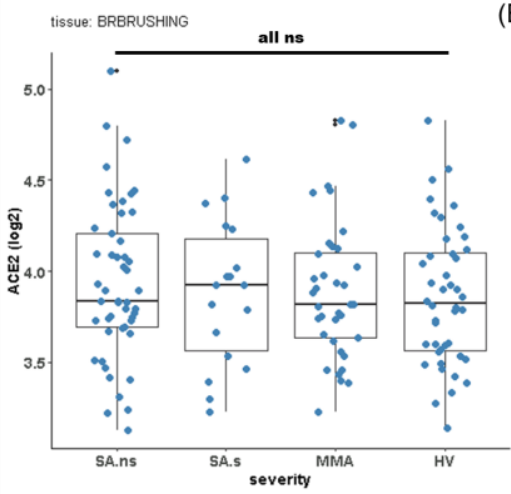

(G)

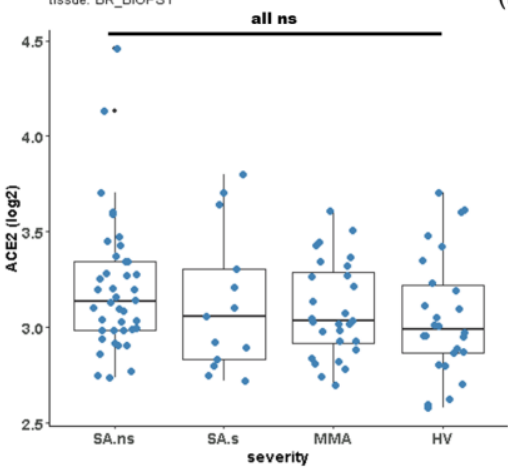

(B)

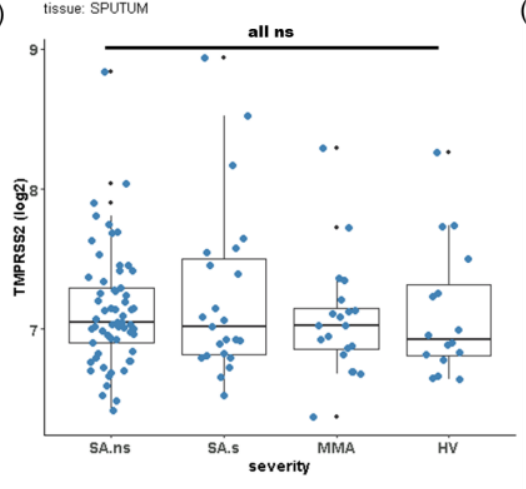

(E) tissue: BRBRUSHING

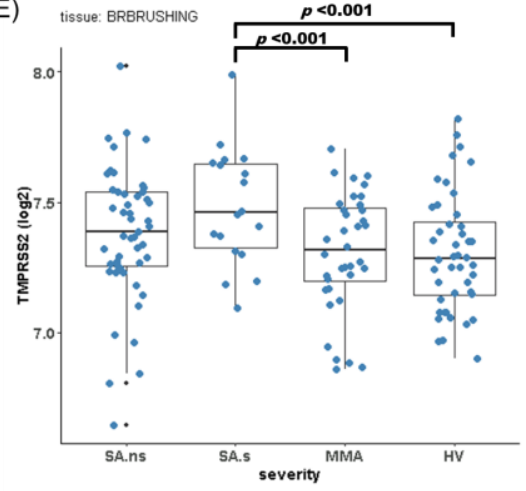

(H)

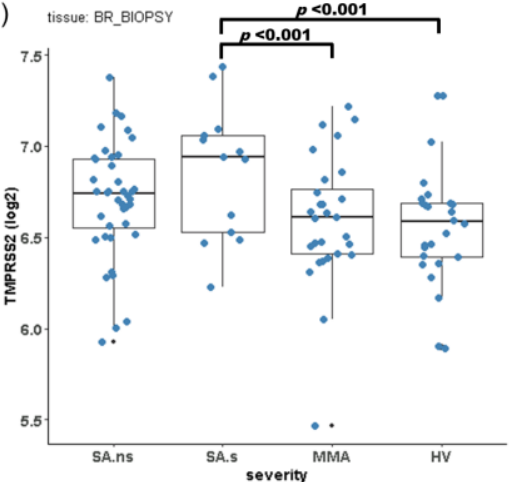

(C)

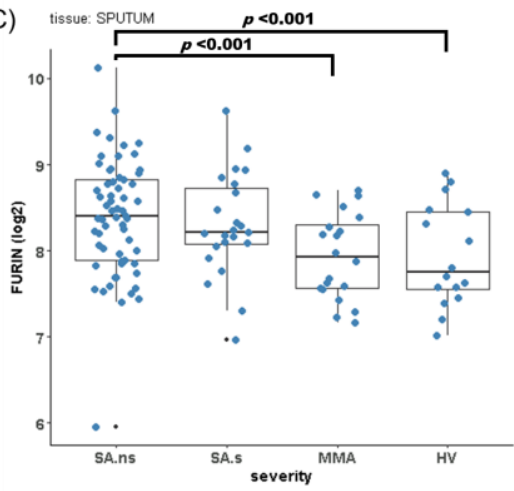

(F)

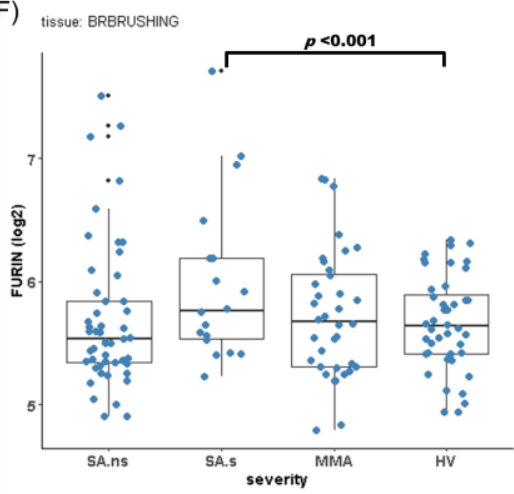

(I)

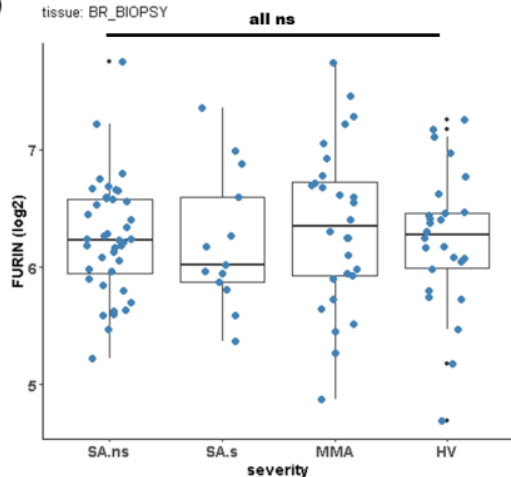


Fig 2.
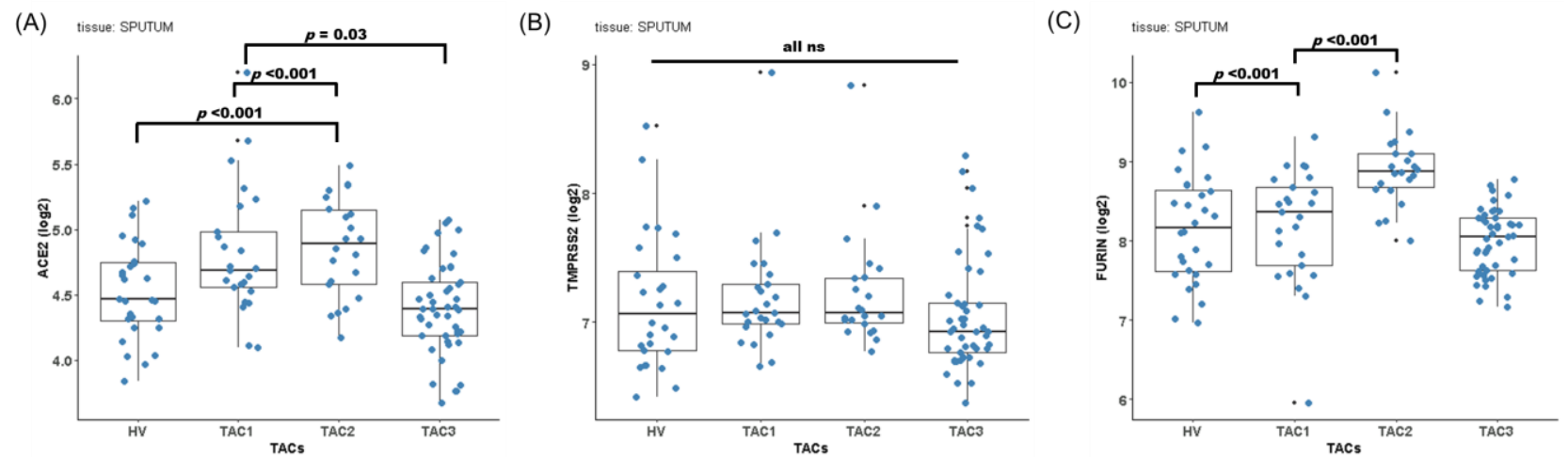

Fig 3.

SARS-CoV-2 host cell receptor and proteases for viral binding and entry

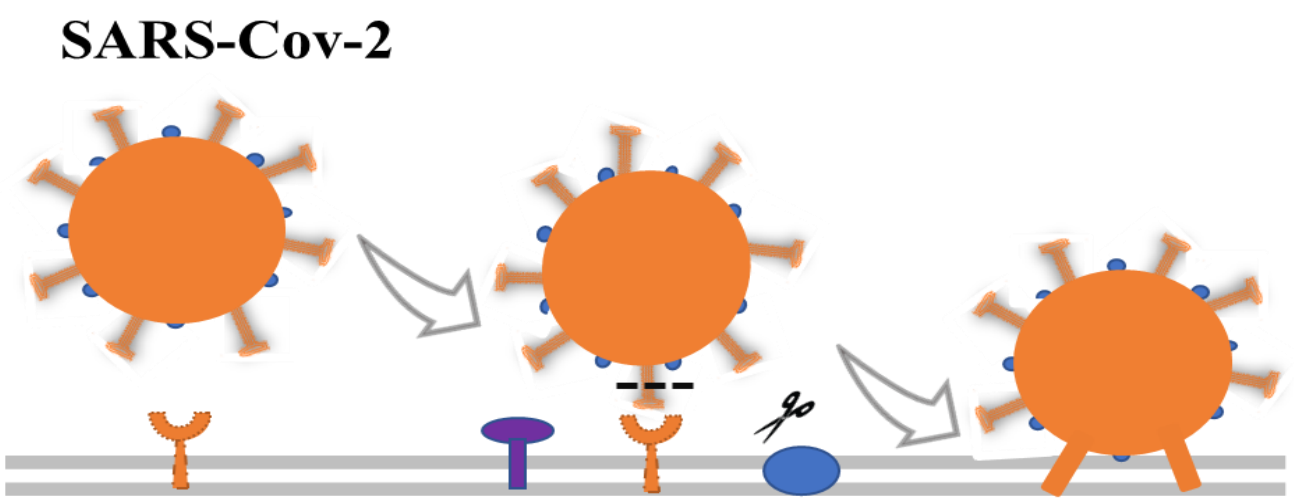

ACE2 TMPRSS2 ACE2 Furin

Expression of ACE2, TMPRSS2, and Furin in lung tissue and sputum

\begin{tabular}{|c|l|l|c|l|l|l|l|l|}
\hline \multicolumn{3}{|c|}{ Sputum } & \multicolumn{3}{c|}{ Bronchial biopsy } & \multicolumn{3}{c|}{ Bronchial brushing } \\
\hline ACE2 & TMPRSS2 & FURIN & ACE2 & TMPRSS2 & FURIN & ACE2 & TMPRSS2 & FURIN \\
\hline$\uparrow$ & $\rightarrow$ & $\uparrow$ & $\rightarrow$ & $\uparrow$ & $\rightarrow$ & $\rightarrow$ & $\uparrow$ & $\uparrow$ \\
\hline \hline \multicolumn{2}{|c|}{ severe non-smoking asthma } & \multicolumn{3}{|c|}{$\begin{array}{c}\text { severe smoking/ex-smoking } \\
\text { asthma }\end{array}$} & \multicolumn{3}{|c|}{$\begin{array}{c}\text { severe smoking/ex-smoking } \\
\text { asthma }\end{array}$} \\
\hline
\end{tabular}


medRxiv preprint doi: https://doi.org/10.1101/2020.06.29.20142091; this version posted July 3 , 2020. The copyright holder for this preprint (which was not certified by peer review) is the author/funder, who has granted medRxiv a license to display the preprint in perpetuity.

All rights reserved. No reuse allowed without permission.

\section{Reference}

1. Guan WJ, Liang WH, Zhao Y, Liang HR, Chen ZS, Li YM, et al. Comorbidity and its impact on 1590 patients with COVID-19 in China: a nationwide analysis. Eur Respir J. 2020;55(5).

2. Wu Z, McGoogan JM. Characteristics of and Important Lessons From the Coronavirus Disease 2019 (COVID-19) Outbreak in China: Summary of a Report of 72314 Cases From the Chinese Center for Disease Control and Prevention. JAMA. 2020.

3. Docherty AB, Harrison EM, Green CA, Hardwick HE, Pius R, Norman L, et al. Features of 20133 UK patients in hospital with covid-19 using the ISARIC WHO Clinical Characterisation Protocol: prospective observational cohort study. BMJ. 2020;369.

4. Petrilli CM, Jones SA, Yang J, Rajagopalan H, O'Donnell L, Chernyak Y, et al. Factors associated with hospital admission and critical illness among 5279 people with coronavirus disease 2019 in New York City: prospective cohort study. BMJ. 2020;369.

5. Yang X, Yu Y, Xu J, Shu H, Xia J, Liu H, et al. Clinical course and outcomes of critically ill patients with SARS-CoV-2 pneumonia in Wuhan, China: a single-centered, retrospective, observational study. Lancet Respir Med. 2020;8(5):475-81.

6. Williamson E, Walker AJ, Bhaskaran KJ, Bacon S, Bates C, Morton CE, et al. OpenSAFELY: factors associated with COVID-19-related hospital death in the linked electronic health records of 17 million adult NHS patients. medRxiv. 2020.

7. Yan R, Zhang Y, Li Y, Xia L, Guo Y, Zhou Q. Structural basis for the recognition of SARS-CoV-2 by full-length human ACE2. Science. 2020;367(6485):1444-8.

8. Hoffmann M, Kleine-Weber H, Schroeder S, Krüger N, Herrler T, Erichsen S, et al. SARS-CoV-2 Cell Entry Depends on ACE2 and TMPRSS2 and Is Blocked by a Clinically Proven Protease Inhibitor. Cell. 2020;181(2):271-80 e8.

9. Coutard B, Valle C, de Lamballerie X, Canard B, Seidah NG, Decroly E. The spike glycoprotein of the new coronavirus 2019-nCoV contains a furin-like cleavage site absent in CoV of the same clade. Antiviral Res. 2020;176:104742.

10. Shaw DE, Sousa AR, Fowler SJ, Fleming $\amalg$, Roberts G, Corfield J, et al. Clinical and inflammatory characteristics of the European U-BIOPRED adult severe asthma cohort. Eur Respir J. 2015;46(5):130821.

11. Athey BD, Braxenthaler M, Haas M, Guo Y. tranSMART: an open source and community-driven informatics and data sharing platform for clinical and translational research. AMIA Summits on Translational Science Proceedings. 2013;2013:6.

12. Kuo C-HS, Pavlidis S, Loza M, Baribaud F, Rowe A, Pandis I, et al. T-helper cell type 2 (Th2) and non-Th2 molecular phenotypes of asthma using sputum transcriptomics in U-BIOPRED. Eur Respir J. 2017;49(2):1602135.

13. Hänzelmann S, Castelo R, Guinney J. GSVA: gene set variation analysis for microarray and RNAseq data. BMC bioinformatics. 2013;14(1):7.

14. Kuo CS, Pavlidis S, Loza M, Baribaud F, Rowe A, Pandis I, et al. T-helper cell type 2 (Th2) and non-Th2 molecular phenotypes of asthma using sputum transcriptomics in U-BIOPRED. Eur Respir J. 2017;49(2):443-55.

15. Menni C, Valdes AM, Freidin MB, Sudre CH, Nguyen LH, Drew DA, et al. Real-time tracking of self-reported symptoms to predict potential COVID-19. Nat Med. 2020.

16. Sungnak $W$, Huang $N$, Becavin $C$, Berg $M$, Queen R, Litvinukova $M$, et al. SARS-CoV-2 entry factors are highly expressed in nasal epithelial cells together with innate immune genes. Nat Med. 2020;26(5):681-7.

17. Peters MC, Sajuthi S, Deford P, Christenson S, Rios CL, Montgomery MT, et al. COVID-19 Related Genes in Sputum Cells in Asthma: Relationship to Demographic Features and Corticosteroids. Am J Respir Crit Care Med. 2020. 
medRxiv preprint doi: https://doi.org/10.1101/2020.06.29.20142091; this version posted July 3, 2020. The copyright holder for this preprint (which was not certified by peer review) is the author/funder, who has granted medRxiv a license to display the preprint in perpetuity.

All rights reserved. No reuse allowed without permission.

18. Jackson DJ, Busse WW, Bacharier LB, Kattan M, O'Connor GT, Wood RA, et al. Association of respiratory allergy, asthma, and expression of the SARS-CoV-2 receptor ACE2. J Allergy Clin Immunol. 2020.

19. Kimura H, Francisco D, Conway M, Martinez FD, Vercelli D, Polverino F, et al. Type 2 Inflammation Modulates ACE2 and TMPRSS2 in Airway Epithelial Cells. J Allergy Clin Immunol. 2020.

20. Ziegler CGK, Allon SJ, Nyquist SK, Mbano IM, Miao VN, Tzouanas CN, et al. SARS-CoV-2 Receptor ACE2 Is an Interferon-Stimulated Gene in Human Airway Epithelial Cells and Is Detected in Specific Cell Subsets across Tissues. Cell. 2020;181(5):1016-35 e19.

21. Bhakta NR, Christenson SA, Nerella S, Solberg OD, Nguyen CP, Choy DF, et al. IFN-stimulated Gene Expression, Type 2 Inflammation, and Endoplasmic Reticulum Stress in Asthma. Am J Respir Crit Care Med. 2018;197(3):313-24. 